\title{
POLSKI NACJONALIZM W SZEROKIEJ PERSPEKTYWIE
}

Bogumił Grott, Dylematy polskiego nacjonalizmu. Powrót do tradycji czy przebudowa narodowego ducha, Wydawnictwo von Borowiecky, Warszawa 2014, ss. 414.

\section{ON POLISH NATIONALISM IN WIDE PERSPECTIVE}

\begin{abstract}
In this book review of Dylematy polskiego nacjonalizmu by B. Grott, the author argues that B. Grott based his study on an interdisciplinary comparative approach. The book presents not only selected Polish nationalist political doctrines in the two factions: the Catholic faction, characterized by traditionalism, and the modernizing faction, characterized by facing the challenges of modernity. The book under review also shows ties between the two factions and between their values and practical use for the nation and its historical success.
\end{abstract}

Key words: history of political thought; Polish nationalism; tradition; national spirit

\section{Streszczenie}

W niniejszej recenzji książki B. Grotta pt. Dylematy polskiego nacjonalizmu... autor przekonuje, iż B. Grott w oparciu o metodę interdyscyplinarną i porównawczą przedstawia nie tylko ksztalt wybranych polskich nacjonalistycznych doktryn politycznych w dwóch odłamach: w katolickim odłamie, o charakterze na wskroś tradycjonalistycznym, i w modernizacyjnym odłamie, zwróconym frontem do wyzwań nowoczesności, ale także ukazuje związki pomiędzy nimi i lansowanymi tam wartościami a praktyką życia narodu i jego powodzenia dziejowego.

KRZYSZTOF KARCZEWSKI,

Słowa kI uczow e: historia myśli politycznej; polski nacjonalizm; tradycja; duch narodowy

Akademia im. Jana Długosza w Częstochowie. Correspondence: krzysztof-karczewski@wp.pl

This is an Open Access article distributed under the terms of the Creative Commons Attribution 3.0 PL License (creativecommons.org/licenses/by/3.0/pl/), which permits redistribution, commercial and non-commercial, provided that the article is properly cited. (C) The Author(s) 2015.

Publisher: Institute of Slavic Studies PAS [Wydawca: Instytut Slawistyki PAN] 

ogumił Grott zalicza się do tych badaczy, którzy konsekwentnie sprzeciwiają się funkcjonującym również w nauce trendom ideologicznym, zmierzającym do narzucenia własnych sposobów odczytywania sensu i wartości minionych wydarzeń i idei ${ }^{1}$. Jego badania charakteryzują się szerokim stosowaniem metody interdyscyplinarnej oraz porównawczej. Podejmuje on też działania badawcze na różnych, nieraz odległych od siebie polach, co daje większą perspektywę widzenia współzależności pomiędzy zjawiskami historycznymi. Przede wszystkim koncentruje się na polskich doktrynach nacjonalistycznych pierwszej połowy XX wieku, ale także i obcych, które często stanowiły źródła inspiracji lub przedmiot ostrej nawet krytyki strony polskiej. Grott przede wszystkim badał dorobek myślowy wczesnej (tzw. pozytywistycznej) endecji, jak i późniejszej jej fazy, ocenianej jako narodowo-katolicka, czyli Stronnictwa Narodowego, Obozu Wielkiej Polski, ugrupowań narodowo-radykalnych: ONR-ABC i RNR-Falanga. Zajmował się także innymi formacjami polskiego nacjonalizmu, mniej płodnymi myślowo, słabszymi pod względem organizacyjnym, z daleko mniejszym poparciem społecznym. Dużo miejsca poświęcił grupie Zadrugi, która stała się kontestatorem formacji narodowo-katolickiej i twórcą własnej oryginalnej rozbudowanej doktryny o charakterze nowego światopoglądu kwalifikowanego niekiedy jako "neopogański”.

Z doktryn i formacji zagranicznych zwracał największą uwage na Action Française, włoski faszyzm, niemiecki völkizm i niemiecki neopoganizm o obliczu szowinistycznym, hiszpański falangizm oraz system portugalski, którego sztandarową postacią był António de Oliveira Salazar, często przywoływany w publicystyce endeckiej lat trzydziestych jako twórca pozytywnie ocenianego tam antyliberalnego systemu polityczno-społecznego opartego na światopoglądzie katolickim. Szeroko zajmował się również B. Grott nacjonalizmem ukraińskim, czego dowodem są redagowane przez niego książki poświęcone temu zagadnieniu i własne artykuły.

Tego rodzaju komparatystyka była wykorzystywana z powodzeniem przez Grotta, służąc do precyzyjnego ujęcia cech formacji polskich. Swoje obserwacje prowadził on z różnych punktów widzenia, nie tylko stricte politologicznego, ale także historycznego, religioznawczego, nie stroniąc od podejmowania wątków socjologicznych czy filozoficznych oraz kulturoznawczych, o ile te warunkowały możliwość pogłębionej interpretacji badanych zjawisk, zachodzących w przeszłości mechanizmów ujawniających się w polityce i w innych przejawach życia społecznego pośrednio związanych ze sferą polityki. Swoją wizję doktryn i ideologii formacji nacjonalistycznych w Polsce i w różnych krajach katolickich Grott oparł na znajomości katolickiej doktryny społecznej czy nawet filozofii tomistycznej i personalizmu, które to elementy szczególnie po ogłoszeniu encykliki Quadragessimo anno stały się czynnikami inspirującymi w kraju, gdzie religia katolicka zdecydowanie dominowała w społeczeństwie. W wypadku innych ruchów politycznych czy doktryn nie odwołujących się do chrześcijaństwa czy nawet z nim zantagonizowanych autor Dylematów... w swoich studiach odwoływał się do innych myślicieli (np. Fryderyk Nietzsche) czy prądów myślowych, które stanowiły dla nich źródła inspiracji lub bazę. W wyniku takiej metody działania recenzowana książka uzyskała szerokie podstawy, a zawarty w niej obraz przedstawianych ruchów politycznych jest wielowymiarowy i przekracza granice jednej dyscypliny, np. historii czy politologii.

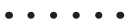

Taką opinię o autorze recenzowanej tu książki zamieszczono w polskim emigracyjnym czasopiśmie naukowym wydawanym w Londynie przez Polskie Towarzystwo Historyczne w Wielkiej Brytanii pt. „Teki Historyczne", t. XIX, 1988/89, s. 162. 
Jak wynika z bibliografii prac B. Grotta zamieszczonej w księdze jubileuszowej ofiarowanej mu w 70. rocznicę urodzin (zob. Łętocha, 2010), publikowat on liczne pozycje wykraczające swoją tematyką daleo nawet poza rozumianą historię myśli (doktryn) politycznej. Znajdujemy tam świadectwa zainteresowań np. międzyetnicznymi stosunkami polsko-niemieckimi na ziemiach Słowian Połabskich, średniowiecznym Śląsku (co było przedmiotem doktoratu B. Grotta), analogicznymi stosunkami na Kresach Wschodnich Rzeczypospolitej, bizantyjskim neopogaństwem czy też teoriami cywilizacyjnymi, jak również wpływem religii na działalność ekonomiczną społeczeństw (teoria Maxa Webera o roli etyki protestanckiej). To właśnie różne elementy tej wiedzy posłużyły autorowi do opisu i interpretacji funkcjonalności doktryn nacjonalistycznych, których kompendium stanowi recenzowana tu jego książka. W ostatnich latach wydał on wraz z zespołem badaczy trzy zbiory artykułów dotyczących ruchów i doktryn nacjonalistycznych². We wstępach do nich Grott przedstawił także swoje stanowisko metodologiczne w kwestii badania nacjonalizmów. Najważniejszym elementem jest tam wskazanie na produktywność określania relacji poszczególnych nacjonalizmów z religiami lub z innymi systemami usiłującymi wejść w ich rolę (np. tzw. neopogaństwo).

Książka Dylematy polskiego nacjonalizmu (Grott, 2014) składa się z pięciu części. Pierwsza z nich, Zagadnienia wprowadzające, zawiera uwagi metodologiczne oraz informacje dotyczące religijności inteligencji polskiej w pierwszej połowie XX wieku, która miała duży wpływ na kształt przewodnich idei polskiego nacjonalizmu, jak też dane o sporach z Kościołem wokół niektórych zasad ideologicznych wczesnej endecji, które w latach międzywojennych zostały wycofane z jej doktryny ze względu na ich niezgodność z duchem katolicyzmu.

Rozdział II, zatytułowany Świat zewnętrzny: widma zagłady - idee destrukcyjne źródła inspiracji, przedstawia zagraniczne idee nacjonalistyczne, z położeniem nacisku na odmienność kulturową niektórych narodów europejskich od Polaków, w tym Niemców, Ukraińców czy Rosjan. W tym rozdziale autor w sposób zwięzły i klarowny podsumuje nacjonalistyczne doktryny polityczne i ich rolę w stosunku do Polski: konserwatywny nacjonalizm niemiecki, a potem tamtejszy narodowy socjalizm, nacjonalizm rosyjski, jak i późniejszy komunizm, faszyzm we Włoszech, ukraiński nacjonalizm Dmytro Doncowa, nacjonalizm integralny Charlesa Maurrasa i jego organizacji Action Française, salazaryzm w Portugalii, frankizm oraz hiszpański falangizm, podkreślając rolę inspirująca, niektórych z nich lub zagrożenia ze strony innych (Niemcy, Rosja sowiecka) dla odbudowanego w 1918 roku państwa polskiego. Całość tego zagadnienia słusznie ukazuje na tle "rewolucji (reakcji) antyliberalnej", jaka miała miejsce w międzywojennej Europie, stając się niejako znakiem tego czasu oraz samego liberalizmu uznawanego w kręgach nacjonalistów za kierunek kosmopolityczny, w swojej istocie antynarodowy i sprzeczny z katolicyzmem, a więc szkodliwy. Kreśląc zagrożenia ze strony „ideologii niemieckiej” (zob. Mosse, 1972, passim), sporo poświęca miejsca tamtejszemu neopoganizmowi, jak i rasizmowi, które to kierunki przewartościowywały dotychczasowy etos polityczny, stając się motorem napędowym dla niemieckiego rewanżyzmu. Tu Grott jawi się jako kontynuator badań profesora Leona Halbana, autora prac o wpływie wartości religijnych na ducha zbiorowego Niemców (por. Halban, 1936, passim, 1946, passim, 1949) oraz innych autorów podejmujących to zagadnienie (por. Suchodolski, 1945, 1947, passim).

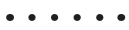

2 Sa to: Nacjonalizm czy nacjonalizmy? - funkcja wartości chrześcijańskich, świeckich i neopogańskich w kształtowaniu idei nacjonalistycznych (Grott, 2006); Różne oblicza nacjonalizmów: polityka - religia - etos (Grott, 2010); Nacjonalizmy rożnych narodów: perspektywa politologiczno-religioznawcza (Grott \& Grott, 2012). 
Zaprezentowanie takiego tła dla wizerunku przewodnich polskich doktryn nacjonalistycznych jest bardzo dobrym sposobem uwypuklenia ich funkcji i właściwości. Pozwala też uniknąć wielu spotykanych uproszczeń i sprowadzić problem nacjonalizmu polskiego, poczynając od połowy lat dwudziestych do właściwych wymiarów, tj. umiejscowić go wśród koncepcji typowo tradycjonalistycznych nieprzyjmujących ani darwinizmu społecznego, ani rasizmu, ani totalitaryzmu, odrzucających również liberalizm. Wszystkie te prądy miały bowiem swoje katolickie ostrze. System, który reprezentowali od lat dwudziestych endecy, angielski historyk H. Trevor-Roper nazwał "klerykalnym konserwatyzmem".

Kolejny III i największy rozdział pt. Ewolucja ku Katolickiemu Państwu Narodu Polskiego stanowi zasadniczy trzon recenzowanej książki. Tu autor w sposób bardzo szczegółowy przedstawia dorobek koncepcyjny całej formacji narodowo-katolickiej, tj. Stronnictwa Narodowego - największej polskiej partii politycznej w II Rzeczypospolitej - i Obozu Narodowo-Radykalnego w obu jego odłamach, a także pomniejszych organizacji nacjonalistycznych tego czasu. Rozdział jest podzielony na część dotyczącą lat przedwojennych oraz czasu okupacji. W tym drugim okresie pojawity się nowe problemy, jak urządzenie Polski po wojnie, przesunięcie jej granic na zachód oraz budowa nowych sojuszy państw między Niemcami a Rosją. Obydwie części rozdziału III omawiają osobno kwestie organizacyjne formacji partyjnych: wartościowanie narodu jako przewodnie dla kierunku nacjonalistycznego, pożądany ustrój państwowy, koncepcje gospodarcze, stosunek do mniejszości narodowych i odrzucenie rasizmu oraz myśl historiozoficzną, która miała tu kapitalne znaczenie światopoglądowe. Polski nacjonalizm katolicki kwestionował bowiem cały nowoczesny świat poczynając od oświecenia, zwracając się do epoki dominacji w życiu Europy religii katolickiej. Chodziło tu o ideę „nowego średniowiecza”3. Ideologia poszczególnych grup nacjonalizmu katolickiego streszczała się więc do lansowanego tam hasła budowy Katolickiego Państwa Narodu Polskiego -- państwa wyznaniowego.

Rozdział IV, Reakcja neopogańska: ruch Zadruga i idee pokrewne czyli nacjonalizm modernizacyjny, jest poświęcony myśli tego środowiska, które z wyraźną agresją kontestowało ewolucję młodych nacjonalistów proweniencji endeckiej ku katolicyzmowi czy nawet fundamentalizmowi religijnemu. Rozdział składa się z podrozdziałów podobnie skonstruowanych jak podrozdziały rozdziału II. Jak widać, autorowi słusznie chodziło o wykazanie różnic poprzez porównanie poszczególnych elementów doktryn. Reakcja Zadrugi jawi się w postaci pewnej formy ideologii pracy i rozwoju. Jest to myśl nawołująca do podniesienia poziomu gospodarczego kraju połączona z mającym ją uzasadniać rodzajem nowej własnej filozofii człowieka i kultury. Żąda ona przebudowy polskiej mentalności jako szkodliwej, gdyż nieprzystającej do sytuacji Polski położonej pomiędzy dwoma potęgami. Myśl ta została wyrażona w kilkunastu książkach pióra przywódcy Jana Stachniuka i wielu artykułach. Dorobek ten był nieproporcjonalnie duży w stosunku do liczby zwolenników koncepcji. Praktycznie nie wywarł żadnego wpływu. Był formą kontestacji. Przypomina on nieco myśl hiszpańskiego secesjonisty z tamtejszej Falangi, również krytykującego wpływ katolicyzmu na rozwój Hiszpanii.

Rozdział ostatni to Zamknięcie, czyli dylematy polskiego nacjonalizmu. Autor podsumowuje swoje badania nad nacjonalizmem polskim dwóch odłamów: katolickiego -- cieszącego się szerokim poparciem społecznym, o charakterze na wskroś tradycjonalistycznym, i modernizacyjnego -- bardzo elitarnego, zwróconego frontem do wyzwań nowoczesności. Na końcu, sięgając nawet do danych z zakresu historii wojskowości, ukazuje skutki

3 Najlepiej wyrazit ją emigrant rosyjski i filozof Mikołaj Bierdiajew w znanej książce Nowe średniowiecze. Na język polski przełożył ją działacz nacjonalistyczny M. Reutt. 
industrialnego niedorozwoju Polski, czego nie chcieli zauważać gospodarczy teoretycy narodowo-katoliccy, wskazując na techniczną słabość armii polskiej, która w wyniku tego w 1939 roku nie była w stanie stawiać skutecznie czoła obydwu agresorom.

Dylematy polskiego nacjonalizmu... (Grott, 2014) przekonywająco przedstawiają nie tylko kształt wybranych doktryn politycznych, ale także ukazują związki pomiędzy nimi i lansowanymi tam wartościami a praktyką życia narodu i jego powodzenia dziejowego. Książka B. Grotta została już zrecenzowana w trzech czasopismach naukowych w kraju oraz W „Zeitschrift für Religions- und Geistesgeschichte” (2014, nr 3/4) w Niemczech.

\section{BIBLIOGRAFIA}

Grott, B. (2014). Dylematy polskiego nacjonalizmu: Powrót do tradycji czy przebudowa narodowego ducha. Warszawa Wydawnictwo Von Borowiecky.

Grott, B. (Red.). (2006). Nacjonalizm czy nacjonalizmy?: Funkcja wartości chrześcijańskich, świeckich i neopogańskich w kształtowaniu idei nacjonalistycznych. Kraków: Zakład Wydawniczy "Nomos".

Grott, B. (Red.). (2010). Różne oblicza nacjonalizmów: Polityka - religia - etos. Kraków: Zakład Wydawniczy "Nomos".

Grott, B., \& Grott, O. (Red.). (2012). Nacjonalizmy różnych narodów: Perspektywa politologiczno-religioznawcza. Kraków: Księgarnia Akademicka.

Halban, L. (1936). Religia w III Rzeszy. Lwów.

Halban, L. (1946). Mistyczne podstawy narodowego socjalizmu. Lublin: Towarzystwo Naukowe Katolickiego Uniwersytetu Lubelskiego.

Halban, L. (1949). Religia starogermańska i jej aktualne znaczenie w Niemczech. Lublin: Towarzystwo Naukowe Katolickiego Uniwersytetu Lubelskiego.

Łętocha, R. (Red.). (2010). Religia, polityka, naród: Studia nad współczesną myślą polityczną. Kraków: Zakład Wydawniczy "Nomos".

Mosse, G. L. (1972). Kryzys ideologii niemieckiej. (T. Evert, Tłum.). Warszawa: Czytelnik.

Suchodolski, B. (1945). Dusza niemiecka w świetle filozofii (1. wyd.). Poznań: Wydawnictwo Instytutu Zachodniego.

Suchodolski, B. (1947). Dusza niemiecka w świetle filozofii (2. wyd.). Poznań: Instytut Zachodni. 